\title{
Learning by Sharing: \\ a Model for Life-Long Learning
}

\author{
Thomas P. T. Thijssen, Rik Maes and Fons T.J. Vernooij (*)
}

Keywords: learning, learning model, learning by sharing, life-long learning, information and communication technology, management curriculum

\begin{abstract}
The dawn of the information society requires a successful combination of life-long learning, entrepreneurial behavior and self-development. Organizations will have to be redefined as generic learning environments for individuals. This emerging perspective presupposes new learning models and new learning infrastructures, examples of which are being developed at the University of Amsterdam.

The model described in this paper involves three types of participants in the learning process and three methods of learning. The integrating concept is called learning by sharing. The participants are: business individuals, teachers/researchers and students. The three methods of learning are: learning by experimenting, learning by investigating, and learning through practice.
\end{abstract}




\section{INTRODUCTION}

The university as an institution is at a decisive moment in its history. It is confronted with numerous outside challenges: the demand as well as the supply of education is globalizing, the coming generation of students differs significantly from preceding ones, the needs for life-long education is replacing the classical learning period between ages 18 and 23, and the new technologies call for new learning models. If concepts like 'learning organization' and 'learning society' are valid, then the university should be the metaphor of the future organization.

However, despite the changes of the past 30 years, the (European) university system has not changed fundamentally. Learning still precedes working. Professors teach students the outcomes of their research, or they teach what they have read before. Students attend lectures, read books and articles, and take exams. Most of the time, the learning processes at the university still take place in the splendid isolation of the ivory tower.

One of the most disturbing problems in universities is the view of learning as a passive process, in which the teacher is perceived as the unquestioned messenger of objective knowledge, and students as the uncritical receivers of this knowledge. Students can complete their study by sheer absorption and accumulation of knowledge.

The actual learning process follows a predetermined route, that is, a fixed curriculum, even though universities tend to emphasize self-guidance on the part of students in carrying out learning tasks. The teacher's role is restricted to designing the curriculum, prescribing the learning path to be followed, and giving students feedback on the extend to which they have acquired the learning content. More-over, most students work their way toward graduation in solitude.

In the past 20 years the Department of Information Management of the University of Amsterdam has experimented with alternative learning models, most of them introduced in a successful postgraduate course in Information Management. The lessons learned from this ongoing experience have now fully been adapted by the Anton Dreesmann Institute for Infopreneurship. In this institute both entrepreneurship and ICT-based learning are at the core of all activities.

Past experiences and new explanations both make clear that the traditional learning model must be replaced by a multi-dimensional learning model. The traditional model is basically one-dimensional (from teacher to student) and sequential (learning precedes working). At the Anton Dreesmann Institute this model has been replaced by the 'Learning by Sharing' model. This essay outlines this new learning model. 


\section{LEARNING BY SHARING: AN ECLECTIC LEARNING MODEL}

Solutions for the problems mentioned in section 1 can actually be found in some existing learning models. These models are the collaborative, the constructivist, and the cognitive (information-processing) models of learning [Leidner and Jarvenpaa, 1995]. The solutions they provide are incorporated and further extended in the Learning by Sharing model.

Firstly, drawn from the collaborative approach, the basic premise of the Learning by Sharing model is that "Learning emerges through the shared understanding of more than one learner" [Leidner and Jarvenpaa, 1995: 270]. It is argued that learning should not be a solitary process: "Knowledge is created as it is shared, and the more it is shared, the more is learned" [Leidner and Jarvenpaa, 1995: 268].

Secondly, drawn from the constructivist approach, the Learning by Sharing model is learner-centered and not teacher-centered. For the student this means that the notion of selfguided studying is complemented with a self-guided educational program [Kaldeway, Haenen, Wils and Westhoff, 1998]. This extends the constructivist belief that "Individuals learn better when they discover things themselves and when they control the pace of learning". In the new model, therefore, students design their own curriculum. They create an individual learning route according to their interests, abilities and learning style.

The teacher in this education à la carte performs the role of coach, and presents the student with various opportunities and possibilities in the design of a personal career in education. The teacher coordinates the entire learning process and gives feedback when and where needed. Ideally, the teaching style will match the learning style of the student [Kaldeway et al., 1998: 274]. The learner-centered approach transforms the passive attitude of the learner into an active attitude. The student constructs his own knowledge structure.

Thirdly, and drawn from the cognitive approach, is the importance of paying explicit attention to the monitoring process students must develop. An essential feature of the Learning by Sharing model is its emphasis on the meta-level of the learning process, that is, the meta-cognitive level. This entails the need to reflect on the learning process, for both teacher and student.

The teacher is in a process of learning to educate and the student is in a process of learning to learn. For the teacher, this means a constant reflection on the teaching approach and improving it when possible. For the student it means self-evaluation of self-guided learning. According to Kaldeway et al. [1998] this self-evaluation includes assessing whether or not the intended learning goals were met.

In order to introduce real-life experiences and hence to establish a learning community, the model of Learning by Sharing introduces a third party into the learning processes: business 
individuals. By bringing in business individuals, the learning processes change drastically. Instead of the traditional student-teacher relationship, the business individuals introduce a real-time and real-life link to everyday practice. Business individuals, students, and teachers learn by interacting in three ways.

\section{LEARNING BY SHARING: A MODEL OF COLLABORATION}

The Learning by Sharing model incorporates the collaboration of three parties in high-level, real-life learning: society as represented by business individuals, universities as represented by teachers/researchers, and educational needs as brought forward by students. These three parties interact in various ways, as shown in REF_Ref444325128 ไh \* MERGEFORMAT Figure 1. Their interactions are shown along the sides of the learning triangle: learning by experimenting, learning by investigating and learning through practice. They will be dealt with in turn.

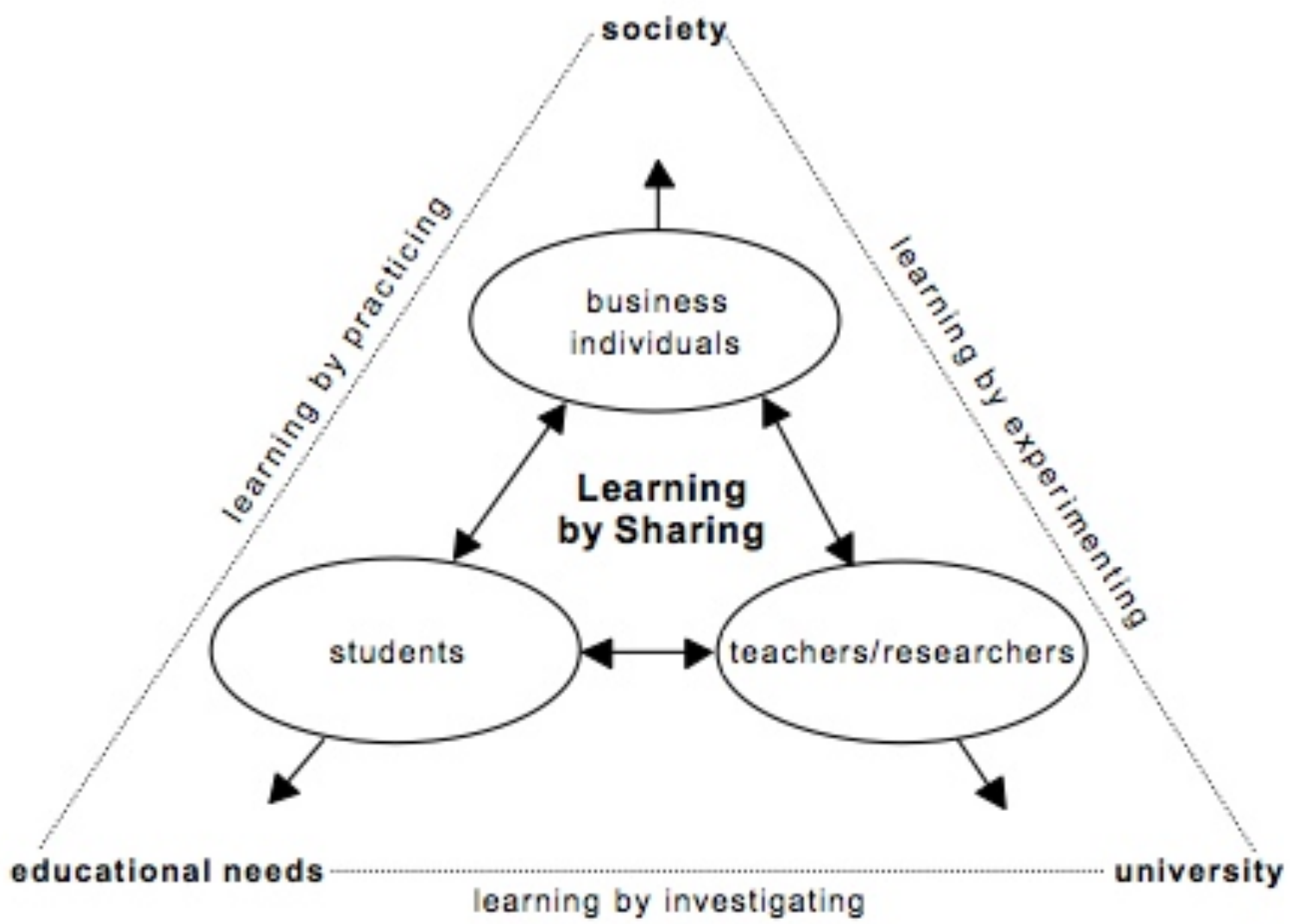




\subsection{Learning by Experimenting: More interaction between Teachers/Researchers and Business Individuals}

A key aspect of enhancing the social character of academic learning is the collaboration of universities with communities of practitioners. Many universities already maintain such partnerships, but don't take full advantage of the possibilities. To achieve this, we call for not only intensification of these partnerships, but also redefinition.

Traditionally these relationships are dominated by the stereotypical view of the practitioner as "... the passive (and theoretically ignorant) recipient of the expertise of academics" [Argyris and Schön, 1996: 34], and of the academic as "... the theoretically well grounded scientist, lacking considerable insight into the real world".

In the Learning by Sharing model, the view of learning by experimenting is an important notion: teachers/researchers and business individuals work together in research projects. Researchers behave as practitioners and practitioners behave as researchers. This results in a sustainable information exchange between the parties involved.

To this end, teachers/researchers in business economics should not only engage in dialogue with other academic communities but also with business individuals actually working in the field. Such dialogue can develop into actual collaboration, both in research and in teaching, on specific subjects of mutual interest.

As far as research is concerned, the direct link between the two communities enables the researchers to identify areas in which to conduct truly innovative research. This ensures the production of useful knowledge, that is, knowledge useful for practitioners [Argyris and Schön, 1996: 43]. The view of researchers as practitioners refers to the empirical testing of a theory, after which it can be adjusted according to (business) practice. Applied research becomes in this way research that matters, research where results are directly applicable.

On the other hand, the view of practitioners as researchers, refers to practitioners putting a theory to everyday use [Argyris and Schön, 1996: 50]. They can adjust practice according to the new theory. Nothing is more practical than a good theory.

For the research community, the combination of new theories and practical topics ensures that the contributions made by the collaboration of researchers and business individuals (joint applied research) are both grounded in theory and relevant to business practice.

At the same time, participation in research activities enables practitioners to significantly enhance their operating capabilities (operational excellence), and to keep abreast of state-ofthe-art developments in academic disciplines. Partnerships between academics and practitioners on key issues in business practice are therefore mutually beneficial. 
As far as teaching is concerned, a second exchange is possible. Business individuals can also be called in as teachers in educational programs: practitioners as teachers. For students this provides an opportunity to learn from first-hand experiences of business individuals. When interacting with the students, the visiting teachers are reflecting on their business practices, because students question particular cases from the perspectives of the theories they have studied.

A final aspect of the interactive relationship learning by experimenting between university and society involves the teaching of researchers/teachers in a business environment: researchers as consultants. In this role the researcher objectively reflects upon business practices from a theoretical point of view.

\subsection{Learning by Investigating: More Interaction between Students and Teachers/Researchers}

Universities today are facing three major educational problems. Firstly, the amount of time needed to introduce new research topics into current curricula results in an education program being continuously outdated.

Secondly, the traditional perspective in which the student is considered a 'knowledge consumer' and the teacher a 'knowledge provider' results in impersonal student-teacher relationships and a one-way flow of knowledge.

Thirdly, since the 1950s research has outgrown teaching in importance [Leggon, 1997: 221-243]. Further integration of research and educational activities should be considered in order to cope with these educational problems.

In the Learning by Sharing model, learning by investigating is an important notion: teachers and students collaborate in research projects. In the course of the research, teachers may find new teaching material. Students compose their personal Education-à-la Carte on the basis of their educational needs and look for teachers to do research with. Teachers act as coaches and facilitate the self-guided education of students.

Such collaboration is fruitful for teachers in enhancing their research and teaching abilities, leading towards the view of teachers as students. It solves the first problem of outdated curricula. For students, participation in research satisfies part of their educational needs. They must explain what they have discovered and can publish their results, leading towards the view of students as teachers.

The collaboration enables students to influence future research by pointing out the topics that interest them. This solves the second problem. that of the one-way flow of knowledge between teacher and student. In situations of collaboration, teaching serves as a way to make research results explicit. It exhilarates students to reflect on their study experiences. Direct response from students on the curriculum may encourage teachers to change their 
teaching method. The integration of research and teaching solves the third problem, that of giving priority to research.

\subsection{Learning through practice: More Interaction between Students and Business Individuals}

In the relationships between university students and business individuals, we notice a gap between learning and working, between theorizing about practice and putting theory into practice. This is why we advocate learning through practice to bridge the gap on the way to life-long learning [cf. Roobeek and Mandersloot, 1998]. One traditional way to solve this problem is through internships or traineeships.

Traditionally, internships are intended to diminish the gap between learning and working. But there are some problems. The first is that a common objective between students and business individuals is often missing [cf. Ghoshal and Bartlett, 1997]. The second is that most internships lack academic challenge because students are exploited as cheap labor. The third is that the duration of internships varies tremendously from several weeks to an entire year [Ontwerp Hoop 1998, 1997]. This makes it difficult to organize supervision of students in their work situation. The fourth problem is that the quality of guidance by both the university and by business individuals often falls short.

In the Learning by Sharing model, learning through practice is an important notion. It bridges the learning to working gap. By intensifying interactions between students and business individuals, the traditional boundaries are blurred. Students and business individuals interact in an earlier stage of the study with high frequency.

During their entire academic career, students should participate in projects with various business individuals. This leads to the view of students as practitioners. For example, students might work one day a week in a business environment and build up relevant working experience.

At the same time, business individuals are confronted with fundamental questions about their company's traditions. They are forced to think about the logic of their behavior in the context of new practices emerging from information and communication technology. This results in the view of practitioners as students. Learning both for students and business individuals becomes a common process.

The tradeoffs between theorizing about practice and putting theory in practice that are part of learning through practice are shown in Table 1 [cf. Roobeek and Mandersloot, 1998]. The student is a learning worker and the business individual is a working learner.

Simultaneously, the student and the business individual learn how to assess the tradeoffs 
between theory and practice. Both become aware of the occurrence of homonyms and synonyms in books and everyday life [Vernooij, 2000] that so easily leads to misunderstandings. The student can reflect on his body of knowledge instantly and learn from it. At the same time, the business individual benefits from the instant employability of the working student.

Learning through practice enables students to carry out research projects in practical situations. For example, research questions for graduation projects might be derived from problems encountered in the business environment. Business individuals gain from possible enhancement of their businesses by the application of new knowledge.

At the same time, both students and business individuals are building a network of relationships. The students are exposed to business individuals from several organizations. The business individuals get acquainted with students from different universities.

In summary, for students, learning through practice is a basis for permanent education, and for business individuals, it is part of life-long learning.

\begin{tabular}{|l|l|}
\multicolumn{1}{|c|}{$\begin{array}{c}\text { Students: } \\
\text { theorizing about practice }\end{array}$} & \multicolumn{1}{c|}{$\begin{array}{c}\text { Business individuals: } \\
\text { putting theory into practice }\end{array}$} \\
\hline Learn and work & Work and learn \\
\hline $\begin{array}{l}\text { Relevant practical situations for theories } \\
\text { (work experience) }\end{array}$ & Relevant theories for practice \\
\hline Instant reflection on body of knowledge & Instant employability of student \\
\hline Do practical research projects & Gain from research projects \\
\hline $\begin{array}{l}\text { Networking (learning to know various } \\
\text { business individuals and organizations) }\end{array}$ & $\begin{array}{l}\text { Networking (learning to know various } \\
\text { students and universities) }\end{array}$ \\
\hline Basis for permanent education & Part of permanent education \\
\hline
\end{tabular}

Table SEQ: Learning through practice

The incorporation of learning through practice as part of the curriculum has repercussions for the university. Firstly, the university must serve as an intermediary between students and business individuals. Secondly, the university must safeguard the academic value of the learning-through-practice relationships. Thirdly, the educational needs of students must be addressed by providing them with relevant ways of thinking and practicing. Finally, the quality of guidance of students must be greatly enhanced.

\section{THE ROLE OF ICT IN LEARNING BY SHARING}

Information and communication technology enables business individuals, teachers/ researchers and students to share their learning, wherever and whenever they want. ICT not only facilitates communication, collaboration and coordination among participants. It also 
facilitates access to educational resources, support of specific learning processes, and development of skills.

Communication tools, like e-mail and ICQ, offer the functionalities needed to support the exchange of information between the parties involved, regardless of temporal and spatial obstacles. These technologies enable the intensification of the three-way communication between business individuals, teachers and students. They offer possibilities for a dialogue between researchers and business individuals, for two-way flow of knowledge between researchers and students, and for a more intense interaction between students and business individuals.

Collaboration tools, like groupware and websites, facilitate experimenting, investigating and practicing together. For example, a group decision room can support the decisionmaking process of formulating joint projects of business individuals, researchers and students.

Coordination tools, like agent technologies and tracking technologies, are necessary to enable the participants to learn in parallel. Activities carried out and results achieved by various participants must be aligned with each other. Agent technologies facilitate the matching of various participants based on the maximization of each individual's needs and the needs of the entire group. Tracking technologies, on the other hand, are useful for keeping track of each individual's performance. They give as well suggestions for adjustments.

ICT facilitates access to educational resources, guidance of the learning process, and development of skills [OECD, 1997: 121, 122]. As far as access to educational resources is concerned, ICT eliminates many temporal and spatial constraints. For example, participants can enroll in any digital course any time, anywhere. And, participants have easy access to worldwide information resources, such as databases, newsgroups, websites and virtual communities.

For example, members of the academic community can gain access both to an enormous range of academic communities worldwide, and to various global business communities. In other words, yesterday's knowledge is widely available, ready to be transformed into tomorrow's knowledge.

The guidance of specific learning processes can be facilitated by ICT in many ways. Firstly, ICT facilitates the creation of a common knowledge base for participants, including frequently asked questions. Secondly, ICT enables immediate feedback on activities carried out by the participants, facilitating real-time parallel learning. Thirdly, based on their individual needs and the tracking history of their performance, intelligent applications could give suggestions for the next step(s) in the learning process.

For example, based on student interests, agent technologies could advise a student to enroll 
in certain courses, or to apply for participation in research projects with certain business individuals and researchers.

Fourthly, ICT supports education-à-la-carte. For example, computer-based training programs (just like books) enable students to learn wherever they want, at their own pace,

in their own way. ICT stimulates the discovery process, whereas the teacher/researcher (or the technology) serves as a coach. As an example, hypermedia let users search and use educational material in a way that suits their own logic.

Finally, to enhance the transfer of knowledge ICT makes multi-perspective education possible. For example, virtual reality enables individuals to approach a problem from several perspectives. A participant might analyze a problem from the perspective of a producer, a merchant, a civil servant or a client. ICT can be useful for customizing education according to different learning styles. It has the potential to facilitate in an intelligent way the structuring of information to match the student's individual way of information processing. In this way, it aids the process of self-guided discovery.

The development of skills is a third final contribution of ICT to Learning by Sharing. Students, as opposed to teachers, are more likely to be early adopters of emerging technologies. Teachers can use their students' knowledge to learn about the possibilities of new technologies in order to enhance their interaction or even their educational program. These new insights could lead teachers to change the way they teach.

The reciprocity of the student-teacher relationship is found again in the way that knowledge sharing improves the interaction between students and teachers. The importance of being skilled in using ICT will become even more important in the future, regardless of the role of the individual. Again, all parties involved can learn from each other.

\section{CONCLUSIONS}

In this essay, an integrative learning model, Learning by Sharing, is described as a model for life-long learning. Its main improvements on existing learning models are the systematic introduction of the external world into the learning process and the reciprocal nature of the interaction process: business individuals with students, students with teachers/researchers, and teachers/researchers with business individuals. All learn from the same learning experiences.

The method, as outlined, is under full implementation at the University of Amsterdam. To support the contacts between participants, meetings are held to bring students, teachers and business individuals together. This results in many ideas, out of which several useful projects have already been developed. Preliminary results show that the use of the Learning by Sharing model increases the speed and depth of learning considerably and that the interaction satisfies the needs for education of all three parties involved. 


\section{REFERENCES}

Argyris, Chris, Donald A. Schön [1996]. Organizational Learning II: Theory, Method, and Practice, Addison-Wesley, Reading, MA

Ghoshal, Sumantra, Christopher A. Bartlett [1997]. The Individualized Corporation: A Fundamentally New Approach to Management, HarperBusiness, New York

Kaldeway, J., J. Haenen, S. Wils, G. Westhoff [1998]. Leren leren in didactisch perspectief, Wolters-Noordhoff, Groningen

Leggon, Cheryl B. [1997]. The Scientist as Academic, in: Daedalus [1997]. Proceedings of the American Academy of Arts and Sciences, Journal of the American Academy of Arts and Sciences

Leidner, Dorothy E., Sirkka L. Jarvenpaa [1995]. "The Use of Information Technology to Enhance Management School Education: A Theoretical View”, MIS Quarterly, pp. 265-291, Sept.

OECD [1997]. ICT as a Tool for Lifelong Learning, in: OECD [1997]. Information Technology Outlook.

Ontwerp HOOP 1998 [1997]. Ontwerp-Hoger Onderwijs en Onderzoek Plan 1998, Ministerie van Onderwijs, Cultuur en Wetenschappen, directie Voorlichting, 16-09-1997

Roobeek, Annemieke J.M., Erik H.U. Mandersloot [1998]. Lerend Werken Werkend Leren: een kennisnetwerk voor duale leertrajecten, Van Gennep, Amsterdam

Vermunt, J.D.H.M.[1992]. Leerstijlen en sturen van leerprocessen in het hoger onderwijs: Naar procesgerichte instructie in zelfstandig denken, Swets \& Zeitlinger, Lisse.

Vernooij, Fons (A.T.J.) [2000]. Tracking down the knowledge structure of students. In: Educational Innovation in Economics and Business V. Business Education for the Changing Workplace (ed. Lex Borghans, Wim H. Gijselaers, Richard G. Milter and John E. Stinson. Dordrecht / Boston / Londen: Kluwer Academic Publishers.

\section{(*) Notes on the authors}

Thomas P. T. Thijssen

Anton Dreesmann Institute for Infopreneurship, Amsterdam, The Netherlands.

Rik Maes

Department of Information Management, University of Amsterdam, The Netherlands.

Fons T.J. Vernooij (www.fons-vernooij.nl)

Graduate School of Teaching, University of Amsterdam, The Netherlands. 